\title{
Seroepidemiology of Toxoplasma gondii and Neospora caninum in Seals around Hokkaido, Japan
}

\author{
Kei FUJII'), Chiharu KAKUMOTO ${ }^{2)}$, Mari KOBAYASHI ${ }^{3)}$, Sachiko SAITO4), Tatsuya KARIYA ${ }^{5)}$, \\ Yukiko WATANABE ${ }^{6}$, Xuenan XUAN ${ }^{5}$, Ikuo IGARASHI ${ }^{5)}$ and Masatsugu SUZUKI ${ }^{1) *}$ \\ ${ }^{1)}$ Laboratory of Wildlife Biology, Graduate School of Veterinary Medicine, Hokkaido University, Sapporo 060-0818, ${ }^{2)}$ Eco Friends, \\ Sapporo 002-0851, ${ }^{3)}$ Laboratory of Aqua Resource Management, Department of Aqua Bioscience and Industry, Tokyo University of \\ Agriculture, Abashiri 099-2493, ${ }^{4)}$ Laboratory of Veterinary Anatomy, and ${ }^{5)}$ National Research Center for Protozoan Diseases, Obihiro \\ University of Agriculture and Veterinary Medicine, Obihiro 080-8555 and ${ }^{6)}$ Institute for Raptor Biomedicine Japan, Kushiro 084-0922, \\ Japan
}

(Received 12 October 2006/Accepted 22 December 2006)

\begin{abstract}
Serological analysis was performed to detect Toxoplasma gondii and Neospora caninum infection in seals in Hokkaido. Serum samples were collected from 322 Kuril harbor seals (Phoca vitulina stejnegeri) at Nosappu, Akkeshi and Erimo, from 46 spotted seals $(P$. largha) at Nosappu, Erimo, Yagishiri Island, Hamamasu and Syakotan, and from 4 ribbon seals (P. fasciata) and a bearded seal (Erignathus barbatus) at Nosappu between 1998 and 2006. Recombinant surface antigen of $T$. gondii (SAG2t) and N. caninum (NcSAG1t) were used as antigens for ELISA to detect antibodies. Antibodies against SAG2t were detected from $4 \%$ of 77 Kuril harbor seals at Nosappu in 2005. Antibodies against NcSAG1t were detected from $2 \%(1 / 66)$ in 2003, 5\% (4/79) in 2004 and $10 \%(8 / 77)$ in 2005 of Kuril harbor seals and $11 \%$ of 9 spotted seals in 2004 sampled at Nosappu. Eight percent of 12 Kuril harbor seals from Akkeshi and $25 \%$ of 4 spotted seals from Erimo in 2005 also contained antibodies against NcSAG1t. These suggest sporadic infection of T. gondii and $N$. caninum in Kuril harbor seals and spotted seals in Hokkaido. Of the ELISA-positive seals, 2 seals having anti-SAG2t antibodies and 3 seals having anti-NcSAG1t antibodies in 2005 were judged to be juveniles that have no maternal antibodies. These suggest that the protozoan infections have occurred in recent years. Infection of terrestrial protozoa such as $T$. gondii and $N$. caninum in seals indicates that the sea environment has been contaminated with protozoa.
\end{abstract}

KEY WORDS: Japan, Neospora caninum, seal, seroepidemiology, Toxoplasma gondii.

J. Vet. Med. Sci. 69(4): 393-398, 2007

Toxoplasma gondii and Neospora caninum, which are apicomplexan protozoa with worldwide distribution, cause neuromuscular disease and abortion through transplacental transmission in warm-blooded hosts $[6,37]$. T. gondii and $N$. caninum infections have been reported mainly in terrestrial mammals and birds, although recently they have been found in wild marine mammals, including several species of seals [8]. T. gondii infection is known to be a major cause of encephalitis in sea otters (Enhydra lutris) $[4,8]$. The ingestion of oocysts in contaminated food or water and the ingestion of infected tissues of intermediate hosts are the two main sources of postnatal $T$. gondii and $N$. caninum infection. Felids and dogs are the only known host that can excrete environmentally resistant oocysts of $T$. gondii and $N$. caninnum, respectively [6, 37]. Miller et al. [20] presented evidence that land-based surface runoff was a significant risk for $T$. gondii infection in sea otters. It is possible that oocysts of these protozoa wash into the sea in runoff contaminated by excrement of cats and dogs. In Hokkaido, influx of runoff contaminated with substances such as pesticides and organic matters into environmental water has been known, and it is particularly serious in the snowmelt season $[29,30]$. Cryptosporidium parvum oocysts that are genetically similar to $C$. parvum infected in cattle have been

\footnotetext{
* Correspondence to: Suzuki, M., Laboratory of Wildlife Biology, Graduate School of Veterinary Medicine, Hokkaido University, Sapporo 060-0818, Japan.
}

detected from river in Hokkaido [38]. If the coastal Hokkaido has been contaminated by terrestrial protozoa, marine mammals may have been infected.

Around Hokkaido, there are 5 species of seals: The Kuril harbor seal (Phoca vitulina stejnegeri), the spotted seal $(P$. largha), the ringed seal ( $P$. hispida), the ribbon seal (P. fasciata) and the bearded seal (Erignathus barbatus) [16]. Kuril harbor seals are distributed along the northwestern Pacific coast [17]. These seals haul out year round on rocky reefs near land and have a strong fidelity to their particular hauling-out site [28]. The four other species migrate in winter and spring, drifting south to Hokkaido with the packed ice [16]. The four species are distributed in the Sea of Japan and the Sea of Okhotsk mainly, although some spotted seals can be found along the Pacific coast all the year round [15, 23, 24]. Miller et al. [21] reported antibodies against $N$. caninum from an encephalitic Pacific harbor seal $(P$. v. richardsi) that had demonstrable $T$. gondii and Sarcocystis neurona in encephalitic lesions. For proper management and conservation of seals, information on the prevalence of the protozoa, which can be the death of seals, is indispensable. The infection of pathogenic protozoa in the seals indicates protozoan contamination of the sea environment, which is a problem not only for marine mammals but also human health. In this study, we surveyed $T$. gondii and $N$. caninum infection in seals around Hokkaido. 


\section{MATERIALS AND METHODS}

Samples: Serum samples were collected from Kuril harbor seals (231 seals), spotted seals (25), ribbon seals (4) and bearded seal (1) at Nosappu; from Kuril harbor seals (16) at Akkeshi; from Kuril harbor seals (75) and spotted seals (6) at Erimo; from spotted seals (2) at Yagishiri Island; from spotted seals (12) at Hamamasu; and from spotted seal (1) at Syakotan (Fig. 1). All samples from Nosappu and Akkeshi were obtained from seals by-caught in salmon fixed nets in the coastal waters from late August to November. Of the samples from Erimo, 46 samples from Kuril harbor seals and 5 samples from spotted seals were collected from seals taken in investigative capture from late June to early July; the remaining 30 samples from Erimo were collected from seals by-caught in salmon fixed nets from late August to November. Samples from Yagishiri Island and Syakotan were collected from seals stranded in May and in April, respectively. One sample from Hamamasu was collected from a spotted seal stranded in January, and others samples from Hamamasu were collected from seals by-caught in gill nets from March to April. Whole blood was collected from the heart of dead seal in fishnet and of stranded dead seal or from the vein of living seal taken in investigative capture, centrifuged, serum separated, and stored at $-20^{\circ} \mathrm{C}$ or $-80^{\circ} \mathrm{C}$. Capture of living seals was conducted under license from the Japanese Ministry of Environment and the Hokkaido Government. To check the condition of animals, the respiration rate and body temperature of the seals were monitored while the living seals were restrained. Body length (nose to tip of tail) was used as index of age [1, 2, 9, 26, 36]. Seals measuring $125 \mathrm{~cm}$ or below were judged to be juveniles (age $<2$ years).

Antigens: Surface antigen 2 (SAG2) of T. gondii $[13,14]$ and surface antigen 1 of $N$. caninum (NcSAG1) [3] were recombined as antigens for enzyme-linked immunosorbent assay (ELISA) to detect antibodies against $T$. gondii and $N$. caninum, respectively. The template DNA for polymerase chain reaction (PCR) was extracted from tachyzoites of the $T$. gondii $\mathrm{RH}$ strain [7] and $N$. caninum $\mathrm{Nc}-1$ strain [6] as described previously $[3,13]$. Two oligonucleotide primers, 5'-ACGAATTCGTCCACCACCGAGACG-3' and 5'ACGAATTCTTCTTGCCCGTGAGA-3', were used to amplify the truncated SAG2 (SAG2t) gene without sequences encoding a highly hydrophobic signal peptide and C-terminus by PCR [33]. The truncated NcSAG1 (NcSAG1t) gene without sequences encoding a hydrophobic signal peptide and a C-terminus was amplified by PCR with two primers, 5'-ACGAATTCATCAGAAAAATCACCT-3, and 5'-ACGAATTCGACCAACATTTTCAGC-3' [3]. The SAG2t gene or NcSAG1t gene was inserted into EcoRI site of the bacterial expression vector, pGEX-4T-3 (Promega, U.S.A.). Each resulting plasmid was designated as pGEX/SAG2t or pGEX/NcSAG1t. pGEX/SAG2t or pGEX/NcSAG1t was expressed as glutathione S-transferase (GST) fusion proteins (GST-SAG2t or GST-NcSAG1t) in Escherichia coli (DH5 $\alpha$ strain) and

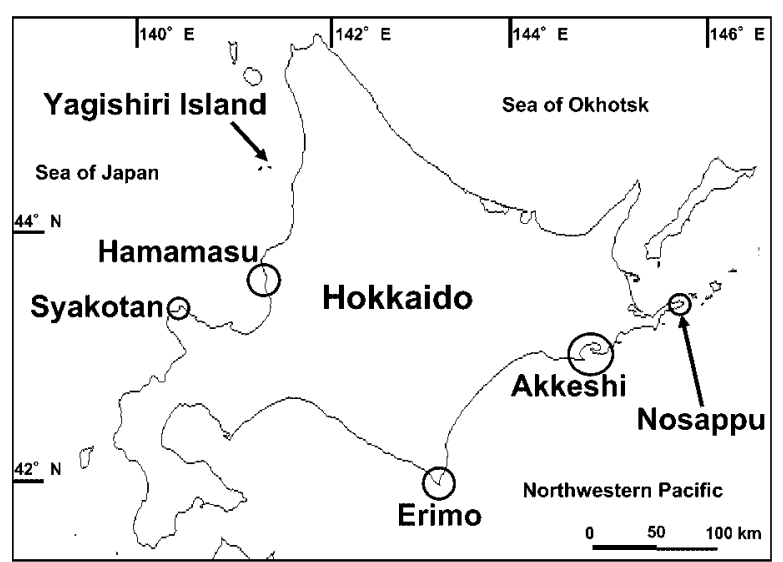

Fig. 1. Map of sampling area. Serum samples were collected from 322 Kuril harbor seals at Nosappu, Akkeshi and Erimo, from 46 spotted seals at Nosappu, Erimo, Yagishiri Island, Hamamasu and Syakotan, and from 4 ribbon seals and a bearded seal at Nosappu between 1998 and 2006.

the proteins were purified by glutathione sepharose $4 \mathrm{~B}$ according to method of Chahan et al. [3].

Enzyme-linked immunosorbent assay (ELISA): ELISA was performed according to modified procedure described previously $[3,10,13,14]$. GST-SAG2t, GST-NcSAG1t or GST was diluted to $5 \mu \mathrm{g} / \mathrm{m} l$ in phosphate-buffered saline (PBS). The antigens were absorbed into each well $(50 \mu \mathrm{ll}$ well) of a 96 -well microtiter plate at $4^{\circ} \mathrm{C}$ for at least $2 \mathrm{hr}$. After the wells were blocked with $1 \%$ bovine serum albumin (BSA) in PBS for $1 \mathrm{hr}$ at room temperature (RT), they were washed with PBST (PBS that contains $0.05 \%$ concentration of Tween 20). Fifty $\mu l$ of sera diluted to $1: 100$ in PBS containing $0.5 \%$ BSA and $0.05 \%$ Tween 20 (BSAPBST) was added to each well. After incubation at RT for 1 $\mathrm{hr}$, the plates were washed with PBST. Fifty $\mu l$ of Peroxidase-conjugated Protein G (Sigma, U.S.A.) diluted to 1:200 in BSA-PBST was added to each well, and the plate incubated for $1 \mathrm{hr}$ at RT. The plates were washed with PBST, and $100 \mu l$ of substrate solution $(0.05 \mathrm{M}$ citrate buffer $\mathrm{pH}$

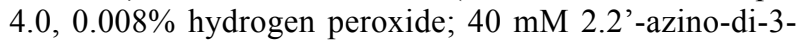
ethyl-benzothiazobine-6-sulfuric acid) was added to each well. After incubation for $30 \mathrm{~min}$ at RT, optical density (OD) of each well was read with a spectrophotometer using a $405 \mathrm{~nm}$ filter. The ELISA result was determined for each sample by taking the mean OD value of two readings with GST-SAG2t or GST-NcSAG1t minus the mean value of two readings with GST. The samples were considered positive if the calculated OD value was $>0.1$. The cutoff value of 0.1 was explained experimentally to be available for ELISA using recombinant SAG2t in cats and using NcSAG1t in cattle $[3,13,14]$.

\section{RESULTS}

Antibodies against SAG2t were detected only in Kuril harbor seals from Nosappu in 2005 (Table 1). The inci- 
Table 1. Number of anti-SAG2t antibodies positive sera collected from seals around Hokkaido, Japan

\begin{tabular}{|c|c|c|c|c|c|c|c|c|c|c|c|c|c|c|c|c|c|c|}
\hline \multirow{3}{*}{ Year } & \multicolumn{7}{|c|}{ Nosappu } & \multirow{2}{*}{\multicolumn{2}{|c|}{$\frac{\text { Akkeshi }}{\text { Kuril harbor seal }}$}} & \multicolumn{4}{|c|}{ Erimo } & \multirow{2}{*}{\multicolumn{2}{|c|}{$\frac{\text { Yagishiri Island }}{\text { Spotted seal }}$}} & \multirow{2}{*}{\multicolumn{2}{|c|}{$\begin{array}{c}\text { Hamamasu } \\
\text { Spotted seal }\end{array}$}} & \multirow{3}{*}{$\begin{array}{c}\text { Syakotan } \\
\begin{array}{c}\text { Spotted } \\
\text { seal }\end{array} \\
\text { Female }\end{array}$} \\
\hline & \multicolumn{2}{|c|}{ Kuril Harbor seal } & \multicolumn{2}{|c|}{ Spotted seal } & \multicolumn{2}{|c|}{ Ribbon seal } & \multirow{2}{*}{$\begin{array}{c}\begin{array}{c}\text { Bearded } \\
\text { seal }\end{array} \\
\text { Male }\end{array}$} & & & \multicolumn{2}{|c|}{ Kuril harbor seal } & \multicolumn{2}{|c|}{ Spotted seal } & & & & & \\
\hline & Male & Female & Male & Female & Male & Fmale & & Male & Female & Male & Female & Male & Female & Male & Female & Male & Female & \\
\hline 1998 & $0 / 2^{a)}$ & $0 / 7$ & $0 / 1$ & - & - & - & - & - & - & - & - & - & - & - & - & - & - & - \\
\hline 1999 & - & - & - & - & - & - & - & - & - & $0 / 6$ & $0 / 2$ & - & - & - & - & - & - & - \\
\hline 2003 & $0 / 31$ & $0 / 35$ & $0 / 3$ & $0 / 3$ & - & $0 / 2$ & $0 / 1$ & - & - & $0 / 9$ & $0 / 6$ & - & - & - & - & - & - & - \\
\hline 2004 & $0 / 47$ & $0 / 32$ & $0 / 7$ & $0 / 2$ & - & - & - & $0 / 2$ & $0 / 2$ & $0 / 16$ & $0 / 12$ & $0 / 2$ & - & - & - & - & - & - \\
\hline 2005 & $1 / 45$ & $2 / 32$ & $0 / 6$ & $0 / 3$ & $0 / 1$ & $0 / 1$ & - & $0 / 7$ & $0 / 5$ & $0 / 15$ & $0 / 9$ & $0 / 3$ & $0 / 1$ & $0 / 1$ & $0 / 1$ & - & - & - \\
\hline 2006 & - & - & - & - & - & - & - & - & - & - & - & - & - & - & - & $0 / 4$ & $0 / 8$ & $0 / 1$ \\
\hline
\end{tabular}

SAG2t is recombinant truncated surface antigen 2 of Toxoplasma gondii without hydrophobic signal peptide.

a) Number of positive/number of sample.

Table 2. Number of anti-NcSAG1t antibodies positive sera collected from seals around Hokkaido, Japan

\begin{tabular}{|c|c|c|c|c|c|c|c|c|c|c|c|c|c|c|c|c|c|c|}
\hline \multirow{3}{*}{ Year } & \multicolumn{7}{|c|}{ Nosappu } & \multirow{2}{*}{\multicolumn{2}{|c|}{$\frac{\text { Akkeshi }}{\text { Kuril harbor seal }}$}} & \multicolumn{4}{|c|}{ Erimo } & \multirow{2}{*}{\multicolumn{2}{|c|}{$\frac{\text { Yagishiri Island }}{\text { Spotted seal }}$}} & \multirow{2}{*}{\multicolumn{2}{|c|}{$\begin{array}{c}\text { Hamamasu } \\
\text { Spotted seal }\end{array}$}} & \multirow{3}{*}{$\begin{array}{c}\begin{array}{c}\text { Syakotan } \\
\text { Spotted } \\
\text { seal }\end{array} \\
\text { Female }\end{array}$} \\
\hline & \multicolumn{2}{|c|}{ Kuril Harbor seal } & \multicolumn{2}{|c|}{ Spotted seal } & \multicolumn{2}{|c|}{ Ribbon seal } & \multirow{2}{*}{$\begin{array}{c}\begin{array}{c}\text { Bearded } \\
\text { seal }\end{array} \\
\text { Male }\end{array}$} & & & \multicolumn{2}{|c|}{ Kuril harbor seal } & \multicolumn{2}{|c|}{ Spotted seal } & & & & & \\
\hline & Male & Female & Male & Female & Male & Fmale & & Male & Female & Male & Female & Male & Female & Male & Female & Male & Female & \\
\hline 1998 & $0 / 2^{a)}$ & $0 / 7$ & $0 / 1$ & - & - & - & - & - & - & - & - & - & - & - & - & - & - & - \\
\hline 1999 & - & - & - & - & - & - & - & - & - & $0 / 6$ & $0 / 2$ & - & - & - & - & - & - & - \\
\hline 2003 & $0 / 31$ & $0 / 35$ & $0 / 3$ & $0 / 3$ & - & $0 / 2$ & $0 / 1$ & - & - & $0 / 9$ & $0 / 6$ & - & - & - & - & - & - & - \\
\hline 2004 & $2 / 47$ & $2 / 32$ & $1 / 7$ & $0 / 2$ & - & - & - & $0 / 2$ & $0 / 2$ & $0 / 16$ & $0 / 12$ & $0 / 2$ & - & - & - & - & - & - \\
\hline 2005 & $4 / 45$ & $4 / 32$ & $0 / 6$ & $0 / 3$ & $0 / 1$ & $0 / 1$ & - & $0 / 7$ & $1 / 5$ & $0 / 15$ & $0 / 9$ & $1 / 3$ & $0 / 1$ & $0 / 1$ & $0 / 1$ & - & - & - \\
\hline 2006 & - & - & - & - & - & - & - & - & - & - & - & - & - & - & - & $0 / 4$ & $0 / 8$ & $0 / 1$ \\
\hline
\end{tabular}

NcSAG1t is recombinant truncated surface antigen 1 of Neospora caninum without hydrophobic signal peptide.

a) Number of positive/number of sample.

dence was $4 \%(3 / 77)$. The range of OD for ELISA-positive sera was $0.11-0.79$ (Table 3 ). Mean OD of negative sera plus three standard deviations was 0.07 , which was $<0.1$.

Antibodies against NcSAG1t were detected in Kuril harbor seals from Nosappu in 2003, 2004 and 2005, in a spotted seal from Nosappu in 2004, in a Kuril harbor seal from Akkeshi in 2005 and in a spotted seal from Erimo in 2005 (Table 2). The incidence of the antibodies in Kuril harbor seals from Nosappu was $2 \%(1 / 66)$ in $2003,5 \%(4 / 79)$ in 2004 and $10 \%(8 / 77)$ in 2005 . That in spotted seals from Nosappu in 2004 was 11\% (1/9). That in Kuril harbor seals from Akkeshi in 2005 was $8 \%(1 / 12)$. That in spotted seals from Erimo in 2005 was $25 \%(1 / 4)$. The range of OD for ELISA-positive sera was $0.11-1.38$ (Table 3 ). Mean OD value of negative sera plus three standard deviations was 0.08 , which was $<0.1$.

No seals had antibodies against both SAG2t and NcSAG1t (Table 3). Of 3 seals having antibodies against SAG2t, 2 seals were judged to be juveniles from their body length $(\leq 125 \mathrm{~cm})$ (Table 3$)$. Of 16 seals having antibodies against NcSAG1t in 2005, 1 Kuril harbor seal from Nosappu, 1 Kuril harbor seal from Akkeshi and 1 spotted seal from Erimo were juveniles. The juvenile Kuril harbor seals having antibodies against the protozoa were taken between September and November (Table 3). Because birthing season of Kuril harbor seals is from mid to late May [28], all juvenile Kuril harbor seals having antibodies against the protozoa were older than 3 months of age. A juvenile spotted seal having antibodies against protozoa was taken in late August. As birthing season of spotted seals is mid to late March [26], the spotted seal having antibodies against the protozoa was older than 5 months.

\section{DISCUSSION}

Antibodies against SAG2t or NcSAG1t were detected in seals from Hokkaido. In previous studies using cats and cattle, recombinant SAG2t of $T$. gondii and NcSAG1t of $N$. caninum were validated as useful antigens which promised a highly sensitive and specific ELISA [3, 13, 14]. The mean OD value of negative sera plus three standard deviation was $<0.1$, which attests to the appropriateness of the cutoff value of 0.1. The results of ELISA with SAG2t suggest sporadic infection of T. gondii in Kuril harbor seals from Nosappu. The results of ELISA with NcSAG1t suggest sporadic infection of N. caninum in Kuril harbor seals and in spotted seals from Nosappu, in Kuril harbor seals from Akkeshi and in spotted seals from Erimo. Of the seals having antibodies against the protozoa, 2 seals having antibodies against SAG2t and 3 seals having antibodies against NcSAG1t in 2005 were judged to be juveniles that were older than 3 months of age. Although little is known about immunity in newborn seals, maternal antibodies (IgG) were transferred to seal pups via the colostrum primarily [34], like cats. Omata et al. [31] showed that maternal antibodies against $T$. gondii in newborn cats were no longer detectable at 2-3 months. These suggest that antibodies against the protozoa detected in juvenile seals that were older than 3 months were 
Table 3. Anti-SAG2t or -NcSAG1t antibodies positive seals sampled at Hokkaido, Japan

\begin{tabular}{|c|c|c|c|c|c|c|c|c|c|}
\hline & ID of seals & Species $^{\text {c) }}$ & $\begin{array}{c}\text { Sampling } \\
\text { year }\end{array}$ & Sampling date & $\begin{array}{c}\text { Sampling } \\
\text { area }\end{array}$ & $\operatorname{Sex}^{\mathrm{d})}$ & $\mathrm{OD}^{\mathrm{e})}$ & Maturity ${ }^{f}$ & $\begin{array}{c}\text { Body length } \\
(\mathrm{cm})\end{array}$ \\
\hline \multirow{3}{*}{ Anti-SAG2t antibodies positive seals ${ }^{a}$} & NZ0504 & Kuril & 2005 & 3 September & Nosappu & $\mathrm{F}$ & 0.11 & $\mathrm{~J}$ & 125 \\
\hline & NZ0567 & Kuril & 2005 & 13 October & Nosappu & $\mathrm{F}$ & 0.30 & A & 146 \\
\hline & NZ0575 & Kuril & 2005 & 18 October & Nosappu & M & 0.79 & $\mathrm{~J}$ & 120 \\
\hline \multirow{16}{*}{ Anti-NcSAG1t antibodies positive seals ${ }^{\text {b) }}$} & NZ0323 & Kuril & 2003 & 9 September & Nosappu & M & 1.38 & A & 133 \\
\hline & NZ0404 & Kuril & 2004 & 1 September & Nosappu & M & 1.25 & A & 152 \\
\hline & NZ0455 & Kuril & 2004 & 7 October & Nosappu & $\mathrm{F}$ & 0.67 & A & 136 \\
\hline & NZ0461 & Kuril & 2004 & 19 October & Nosappu & M & 0.12 & A & 142 \\
\hline & NZ0481 & Kuril & 2004 & 11 November & Nosappu & $\mathrm{F}$ & 0.15 & A & 144 \\
\hline & NG0407 & Spotted & 2004 & 4 November & Nosappu & $\mathrm{M}$ & 0.53 & A & 126 \\
\hline & NZ0511 & Kuril & 2005 & 5 September & Nosappu & $\mathrm{M}$ & 0.31 & A & 167 \\
\hline & NZ0519 & Kuril & 2005 & 6 September & Nosappu & $\mathrm{F}$ & 0.66 & A & 147 \\
\hline & NZ0526 & Kuril & 2005 & 7 September & Nosappu & $\mathrm{M}$ & 0.11 & A & 152 \\
\hline & NZ0533 & Kuril & 2005 & 12 September & Nosappu & $\mathrm{F}$ & 0.86 & A & 133 \\
\hline & NZ0554 & Kuril & 2005 & 26 September & Nosappu & $\mathrm{F}$ & 0.14 & A & 129 \\
\hline & NZ0560 & Kuril & 2005 & 1 October & Nosappu & $\mathrm{M}$ & 0.93 & A & 129 \\
\hline & NZ0574 & Kuril & 2005 & 18 October & Nosappu & $\mathrm{F}$ & 1.24 & A & 137 \\
\hline & NZ0586 & Kuril & 2005 & 17 November & Nosappu & $\mathrm{M}$ & 0.35 & $\mathrm{~J}$ & 118 \\
\hline & AZ0515 & Kuril & 2005 & 14 September & Akkeshi & $\mathrm{F}$ & 0.15 & $\mathrm{~J}$ & 108 \\
\hline & EG05101 & Spotted & 2005 & 28 August & Erimo & $\mathrm{M}$ & 0.12 & $\mathrm{~J}$ & 121 \\
\hline
\end{tabular}

a) SAG2t is recombinant truncated surface antigen 2 of Toxoplasma gondii without hydrophobic signal peptide.

b) NcSAG1t is recombinant truncated surface antigen 1 of Neospora caninum without hydrophobic signal peptide.

c) Kuril or Spotted indicates Kuril harbor seal or spotted seal, respectively.

d) $\mathrm{M}$ or $\mathrm{F}$ indicates male or female, respectively.

e) Optical density read in ELISA using SAG2t or NcSAg1t with $405 \mathrm{~nm}$ filter.

f) Seals measuring $125 \mathrm{~cm}$ or less, were judged to be juvenile (age $<2$ years). J or A indicates juvenile or adult (age $\geq 2$ years), respectively.

not maternal antibodies. Then the protozoan infections are thought to have occurred in recent years. The incidence of antibodies against NcSAG1t was higher than that of antibodies against SAG2t. The antibodies against $N$. caninum had been detected in a killer whale (Orcinus orca) stranded at Aidomari, Shiretoko, Hokkaido [32]. The marine mammals around Hokkaido may be exposed more commonly to $N$. caninum than to $T$. gondii. For definitive diagnosis, detection of the protozoa or protozoan DNA from the tissue of seals is required.

The infections of terrestrial protozoa were suggested in Kuril harbor seals from Nosappu and Akkeshi. Kuril harbor seals are distributed from Erimo to Nosappu along the Pacific coast of Hokkaido. The distance from Erimo to Akkeshi is about $170 \mathrm{~km}$, and there are no hauling-out sites for Kuril harbor seals between the two areas [17]. Analysis of mtDNA indicated that movement of the Kuril harbor seals between Erimo and eastern Hokkaido (from Akkeshi to Nosappu) is restricted [39]. The difference in incidence of Kuril harbor seals with antibodies against the protozoa between eastern Hokkaido and Erimo may relate to the exiguity of contact between the Kuril harbor seals inhabiting eastern Hokkaido and the Kuril harbor seals inhabiting Erimo. The movement range of Kuril harbor seals in eastern Hokkaido is presumed to be between Akkeshi and southern Kuril Islands, because most of the Kuril harbor seals bycaught in fixed salmon nets at Nosappu are considered to be from the Habomai Islands [12]. It is thought that there is place somewhere in the movement range (from Akkeshi to southern Kuril Islands) contaminated by the protozoan that may infect Kuril harbor seals. Spotted seals are kwon for the great range of movement [22], and the spotted seals tagged at Erimo were recovered at Akkeshi (Saito, unpublished). Therefore, although a spotted seal sampled at Erimo had antibodies against $N$. caninum, it is possible that the spotted seal was not infected at Erimo. The spotted seal might have been infected with $N$. caninum somewhere excluding Erimo before moving to Erimo. The antibodies against $T$. gondii and $N$. caninum were not found in seals from the Sea of Japan in this study. However, we must note that few samples were collected from the area, and all were from spotted seals. Due to the fidelity to costal area, Kuril harbor seals may be more prone to contamination from land than other species.

Runoff is considered to carry oocysts of terrestrial protozoa such as $T$. gondii and $N$. caninum from land into the sea $[5,20]$. The infection of the terrestrial protozoa in the Kuril harbor seals of eastern Hokkaido suggests that range of Kuril harbor seals in eastern Hokkaido contains water contaminated with terrestrial protozoa. T. gondii has been reported in domestic cats in Japan and recent studies have shown 4\% positive rates in Hokkaido [19]. Sawada et al. [35] reported $31 \%$ positive rates on dogs in dairy farms suffering from cattle abortion due N. caninum and 7\% in urban area in Japan. Epidemiological investigation in animals at waterfront area is required to estimate risk of contamination with the protozoa from land to sea. If infections of these protozoa increase and spread on land or the flow of proto- 
zoa-contaminated water from land to the sea increase, contamination of sea environment also will increase.

There are three possible routes by which seals could become infected with $T$. gondii or $N$. caninum: ingestion of sporulated oocysts, ingestion of bradyzoite cysts in the tissues of intermediate hosts, or vertical transmission. The infection via intermediate host is unlikely because seals do not prey on warm-blooded animals, which are recognized being intermediate hosts. It is unknown whether vertical transmission of the protozoa in seals is a significant path of infection. In sea otters, vertical transmission does not seem to be the primary cause of $T$. gondii infection [5]. Gajadhar et al. [11] demonstrated experimentally that oocysts that are shed by cats and sporulate are capable of establishing infection in seals. The infective oocysts of $T$. gondii can survive for months in seawater [18]. Several studies have demonstrated that oocysts and cysts of pathogenic protozoa including $T$. gondii are concentrated by clams, mussels and oysters during filter-feeding activity [5]. For sea otters, shellfishes that concentrate the oocysts are considered to be a route of infection [5]. Because Kuril harbor seals and spotted seals feed mainly on fish and cephalopod [27], shellfishes are not thought to be a principal route of $T$. gondii and $N$. caninum infection in these seals. North Pacific giant octopus (Paroctopus dofleini) is the most important prey for Kuril harbor seals and spotted seals at Nosappu [27]. As these octopuses feed on shellfishes [25], the seals are potentially to ingest secondary the oocysts concentrated by shellfishes via the octopuses. For confirming the route of protozoan infection in the sea, status of contamination in various marine organisms by protozoa must be researched.

For both marine mammal and human health, contamination of marine environment and marine organisms by pathogenic protozoa should be monitored, and appropriate runoff management is necessary. Feces of domestic animals including cats and dogs must be disposed properly to prevent environmental contamination with protozoan oocysts contained in the feces.

ACKNOWLEDGMENTS. We wish to thank the Erimo Seal Club, Kuril Harbor Seal Research Group, Ms. E. Nakagawa (Hokkaido University), Dr. K. Hattori (Hokkaido National Fisheries Research Institute), Mr. K. Niimura (Marine Fisheries Research and Development Center), Mr. T. Fujita (Sea Lions Club), Mr. Y. Kouno and the fishermen and Fishery Cooperatives of Habomai, Akkeshi, Erimo and Hamamasu for their assistance in capturing and sampling. We also thank Dr. Y. Sakoda (Hokkaido University) for advice regarding laboratory analysis. Seal capture was conducted under license from the Japanese Ministry of the Environment and the Hokkaido Government. This work was supported by the Japanese Ministry of the Environment.

\section{REFERENCES}

1. Burns, J. J. 1981. Ribbon seal Phoca fasciata Zimmermann, 1783. pp 89-109. In: Handbook of Marine Mammals (Ridg- way, S.H. and Harrisson, R.J. eds.), Academic Press, London.

2. Burns, J. J. 1981. Bearded seals Erignathus barbatus Erxleben, 1777. pp 145-170. In: Handbook of Marine Mammals (Ridgway, S.H. and Harrisson, R.J. eds.), Academic Press, London.

3. Chahan, B., Gaturaga, I., Huang, X., Liao, M., Fukumoto, S., Hirata, H., Nishikawa, Y., Suzuki, H., Sugimoto, C., Nagasawa, H., Fujizaki, K., Igarashi, I., Mikami, T. and Xuan, X. 2003. Serodiagnosis of Neospra caninum infection in cattle by enzyme-linked immunosorbent assay with recombinant truncated NcSAG1. Vet. Parasitol. 118: 177-185.

4. Cole, R. A., Lindsay, D. S., Howe, D. K., Roderick, C. L., Dubey, J. P., Thomas, N. J. and Baeten, L. A. 2000. Biological and molecular characterizations of Txoplasma gondii strains obtained from southern sea otters (Enhydra lutris nereis). $J$. Parasitol. 86: 526-530.

5. Conrad, P. A., Miller, M. A., Kreuder, C., James, E. R., Mazet, J., Dabritz, H., Jessup, D. A., Gulland, F. and Grigg, M. E. 2005. Transmission of Toxoplasma: Clues from study of sea otters as sentinels of Toxoplasma gondii flow into the marine environment. Int. J. Parasitol. 35: 1155-1168.

6. Dubey, J. P. 2003. Review of Neospora caninum and neosporosis in animals. Korean J. Parasitol. 41: 1-16.

7. Dubey, J. P. and Frenkel, J. K. 1988. Toxoplasmosis of rats: a review, with considerations of their value as an animal model and their possible role in epidemiology. Vet. Parasitol. 77: 132.

8. Dubey, J. P., Zarnke, R., Thomas, N. J., Wong, S. K., Van Bonn, W., Briggs, M., Davis, J. W., Ewing, R., Mense, M., Kwok, O. C. H., Romand, S. and Thulliez, P. 2003. Toxoplasma gondii, Neospora caninum, Sarcocystis neurona, and Sarcocystis canis-like infections in marine mammals. Vet. Parasitol. 116: 275-296.

9. Fujii, K., Ishikawa, T., Watanabe, Y., Saito, S., Nakagawa, E. and Kobayashi, Y. 2005. Tagging and measuring of Harbor seals (Phoca vitulina stejnegeri) in Erimo Cape, Japan. Bulletin of the Erimo Town Museum. 2: 1-8 (in Japanese with English abstract).

10. Fujii, K., Sato, H., Kakumoto, C., Kobayashi, M., Saito, S., Tatsuya, K., Watanabe, Y., Sakoda, Y., Kai, C., Kida, H. and Suzuki, M. 2006. Seroepidemiological survey of morbillivirus infection in Kuril harbor seals (Phoca vitulina stejnegeri) of Hokkaido, Japan. Jpn. J. Vet. Res. 54: 109-117.

11. Gajadhar, A. A., Measures, L., Forbes, L. B., Kapel, C. and Dubey, J. P. 2004. Experiental Toxoplasma gondii infection in grey seals (Halichoerus grypus). J. Parasitol. 90: 255-259.

12. Hayama, S., Uno, H. and Wada, K. 1986. A migration model based on sex and age composition of Kuril seals captured along the coast of Nemuro Peninsula, Hokkaido. pp. 140-157. In: Ecology and Protection of Kuril Seal. (Wada, K. ed.), Tokai University Press, Tokyo (in Japanese with English abstract).

13. Huang, X., Xuan, Hirata, H, Yokoyama, N., Xu, L., Suzuki, N. and Igarashi, I. 2004. Rapid immunochromatographic test using recombinant SAG2 for detection of antibodies against Toxoplasma gondii in cats. J. Clin. Microbiol. 42: 351-353.

14. Huang, X., Xuan, X., Kimbita, E. N., Battur, B., Miyazawa, T., Fukumoto, S., Mishima, M., Makala, L. H., Suzuki, H., Sugimoto, C., Nagasawa, H., Fujisaki, K., Mikami, T. and Igarashi, I. 2002. Development and evaluation of an enzyme-linked immunosorbent assay with recombinant SAG2 for diagnosis of Toxoplasma gondii infection in cats. J. Parasitol. 88: 804-807.

15. Ishikawa, S. 2006. Marine mammal watching at Cape Erimo. Isana 44: 11-13 (in Japanese).

16. Itoo, T. 1999. Pinniped, zoological character and Japanese Pin- 
nipeds. pp. 3-40. In: Pinniped, Natural History of Sea Lion and Seal (Wada, K. and Ito, T. eds.), Tokai University Press, Tokyo (in Japanese).

17. Itoo, T. and Shukunobe, T. 1986. Number and present of Kuril seal. pp. 18-58. In: Ecology and Protection of Kuril Seal (Wada, K. ed.), Tokai University Press, Tokyo (in Japanese with English abstract).

18. Lindsay, D. S., Collins, M. V., Mitchell, S. M., Cole, R. A., Flick, G. J., Wetch, C. N., Lindquist, A. and Dubey, J. P. 2003. Sporulation and survival of Toxoplasma gondii oocysts in seawater. J. Eukaryot. Microbiol. 50: 687-688.

19. Maruyama, S., Kabeya, H., Nakao, R., Tanaka, S., Sakai, T., Xuan, X., Katsube, Y. and Mikami, T. 2003. Seroprevalence of Bartonella henselae, Toxoplasma gondii, FIV and EeLV infections in domestic cats in Japan. Microbiol. Immunol. 47: 147153.

20. Miller, M. A., Gardner, I. A., Kreuder, C., Paradies, D. M., Worcester, K. R., Jessup, D. A., Dodd, E., Harris, M. D., Amen, J. A., Packham, A. E. and Conrad, P. A. 2002. Coastal freshwater runoff is a risk factor for Toxoplasma gondii infection of southern sea otters (Enhydra lutris neteis). Int. J. Parasitol. 32: 997-1006.

21. Miller, M. A., Sverlow, K., Crosbie, P. R., Barr, B. C., Lowenstine, L. J., Gulland, F. M., Packham, A. and Conrad, P. A. 2001. Isolation and characterization of two parasitic protozoa from a Pacific harbor seal (Phoca vitulina richardsi) with meningoencephalomyelitis. J. Parasitol. 87: 816-822.

22. Mizuno, A. W., Onuma, M., Takahashi, M. and Ohtaishi, N. 2003. Population genetic structure of the spotted seal Phoca largha along the coast of Hokkaido, based on mitochondrial DNA sequences. Zool. Sci. 20: 783-788.

23. Mizuno, A. W., Suzuki, M. and Ohtaishi, N. 2001. Distribution of the spotted seal Phoca largha along the coast of Hokkaido, Japan. Mammal Study. 26: 109-118.

24. Mizuno, A. W., Wada, A., Ishinazaka, T., Hattori, K., Watanabe, Y. and Ohtaishi, N. 2002. Distribution and abundance of spotted seals Phoca largha and ribbon seals Phoca fasciata in the southern Sea of Okhotsk. Ecol. Res. 17: 79-96.

25. Nagasawa, K. and Torisawa, M. 1991. Fishes and Marine Invertebrates of Hokkaido: Biology and Fisheries, Kita-Nihon Kaiyo Center, Hokkaido (in Japanese).

26. Naito, Y. and Nishiwaki, M. 1972. The growth of two species of the harbor seal in the adjacent water of Hokkaido. Sci. Rep. Whales Res. Inst. 24: 127-144.

27. Nakaoka, T., Hamanaka, T., Wada, K. and Tanahashi, K. 1986. Food and feeding habits of Kuril and spotted seals captured at the Nemuro Peninsula. pp. 103-125. In: Ecology and Protection of Kuril Seal (Wada, K. ed.), Tokai University Press, Tokyo (in Japanese with English abstract).
28. Niizuma, A. 1986. Socio-ecology and reproductive strategy of the Kuril seal. pp. 59-102. In: Ecology and Protection of Kuril Seal (Wada, K. ed.), Tokai University Press, Tokyo (in Japanese with English abstract).

29. Numabe, A. and Nagahora, S. 2006. Estimation of pesticide runoff from paddy fields to rural rivers. Water Sci. Technol. 53: 139-146.

30. Ohmura, K. and Kurokawa, H. 1991. The effect of surface wash-off water at a snow melting period on the water rivers. Bull. Hokkaido Pref. Agric. Exp. Station. 62: 35-45 (in Japanese with English abstract).

31. Omata, Y., Oikawa, H., Kanda, M., Mikazuki, K., Dilorenzo, C., Claveria, F. G., Takahashi, M., Igarashi, I., Saito, A. and Suzuki, N. 1994. Transfer of antibodies to kittens from mother cats chronically infected with Toxoplasma gondii. Vet. Parasitol. 52: 211-218.

32. Omata, Y., Umeshita, Y., Watari, M., Tachibana, M., Sasaki, M., Murata, K. and Yamada, T. K. 2006. Investigation for presence of Neospora caninum, Toxoplasma gondii and Brcellaspecies infection in killer whales (Orcinus orca) mass-stranded on the coast of Shiretoko, Hokkaido, Japan. J. Vet. Med. Sci. 68: $523-526$.

33. Parmley, S. F. G. D., Sgarlato, J., Mark, J. B. P. and Reminaton, J. S. 1992. Expression, characterization, and serological reactivity of recombinant surface antigen P22 of Toxoplasma gondii. J. Clin. Microbiol. 30: 1127-1133.

34. Ross, P. S., de Swart, R. L., Visser, I. K. G., Vedder, L. J., Murk, W., Bowen, W. D. and Osterhaus, A. D. M. E. 1994. Relative immunocompetence of the newborn harbour seal, Phoca vitulina. Vet. Immunol. Immunopathol. 42: 331-348.

35. Sawada, M., Park, C. H., Kondo, H., Morita, T., Shimada, A., Yamane, I. and Umemura, T. 1998. Serological survey of antibody to Neospora caninum in Japanese Dogs. J. Vet. Med. Sci. 60: $353-354$.

36. Suzuki, M. and Yamashita, T. 1986. Sexual maturity and developmental stages of Kuril seals. pp. 179-194. In: Ecology and Protection of Kuril Seal (Wada, K. ed.), Tokai University Press, Tokyo (in Japanese with English abstract).

37. Tenter, A. M., Heckeroth, A. R. and Weiss, L. M. 2000. Toxoplasma gondii: from animals to humans. Int. J. Parasitol. 30: $1217-1258$.

38. Tsushima, Y., Karanis, P., Kamada, T., Xuan, X., Makala, L. H. C., Tohya, Y., Akashi, H. and Nagasawa, H. 2003. Viability and infectivity of Criptosporidium parvum oocyst in river water in Hokkaido, Japan. J. Vet. Med. Sci. 65: 585-589.

39. Watanabe, Y. 2000. Population Genetic Studies of Kuril Harbor Seal (Phoca vitulina stejnegeri) in Hokkaido, Japan, by mtDNA Sequences. The Graduation Thesis, Obihiro University of Agriculture and Veterinary Medicine, Japan. 